\title{
Intervensi Ergonomi Pada Perancangan Meja Las Untuk Sekolah Vokasi
}

\author{
Suhartono ${ }^{1}$, Iva Mindhayani ${ }^{2}$ \\ ${ }^{1,2)}$ Fakultas Sain danTeknologi, Program Studi Teknik Industri, Universitas Widya Mataram \\ Dalem Mangkubumen KT.III/237 Yogyakarta \\ Email: sharjosaputro@gmail.com, ivamindhayani@gmail.com
}

\begin{abstract}
ABSTRAK
Untuk memenuhi kebutuhan laboratorium pengelasan, pelatihan pengelasan listrik dan asetilena, pengelasan yang dapat digunakan untuk semua pekerja produktif, seks dan untuk orang yang sehat atau tidak valid, terutama cacat kaki yang tidak valid, sangat penting untuk merancang meja pengelasan. Selain memberikan kenyamanan, meja juga memberikan kemudahan, keamanan, dan mengurangi kelelahan otot. Posisi pengelasan tabler dapat dirancang yang sesuai dengan kebutuhan semua posisi pengelasan. Namun demikian, untuk orang Indonesia (orang Asia pada umumnya), dimensi dapat diperoleh dengan perhitungan sebagai berikut: ketinggian meja geser adalah $2165 \mathrm{~mm}$, tinggi meja di posisi pengelasan kepala adalah $17010 \mathrm{~mm}$ untuk posisi berdiri dan $1040 \mathrm{~mm}$ untuk posisi tapak. Sementara itu pada posisi pengelasan vertikal dan horizontal, ketinggian meja adalah $890 \mathrm{~mm}$ untuk posisi berdiri dan $530 \mathrm{~mm}$ untuk posisi tapak. Penyesuaian meja pengelasan untuk posisi pengelasan rata adalah $700 \mathrm{~mm}$ untuk posisi berdiri dan $340 \mathrm{~mm}$ untuk posisi duduk di kursi roda.
\end{abstract}

Kata kunci: pengelasan, listrik, meja

\begin{abstract}
To meet the need iof welding laboratory, electrical welding training and acetylene, welding that can be used for all productive workers, sex and for healthy or invalid people, especially invalid defect of leg, it is very important to design the welding table. Instead of giving comfortable, the table also give easiness, security and reduce muscle fatigue. The position of welding tabler can be designed that fit the need of all welding position. Nevertheless, for Indonesian people (Asian people in general), the dimension can be obtained with the following calculation : the height of table sliding is $2165 \mathrm{~mm}$, the height of table in over head welding position is $17010 \mathrm{~mm}$ for standing position and $1040 \mathrm{~mm}$ for siting position. Meanwhile in the vertical and horizontal welding position, the height of the table is $890 \mathrm{~mm}$ for standing position and $530 \mathrm{~mm}$ for siting position. The adjustment of the welding table for flat welding position is $700 \mathrm{~mm}$ for standing position and $340 \mathrm{~mm}$ for sitting position on the wheel chair.
\end{abstract}

Keyword : welding, electrical, table

\section{PENDAHULUAN}

Proses pengelasan adalah bagian yang tidak dapat dipisahkan dari semua tahapan kegiatan baik dalam perencanaan, perakitan dan perawatan suatu benda yang berbahan dasar logam. Keberadaan meja las sangat dibutuhkan dalam rangka memenuhi tahapan proses pengelasan tersebut. Saat ini meja las yang tersedia masih kurang fleksibel terhadap posisi dan cara pengelasan yang dibutuhkan.

Dalam laboratorium pengelasan yang kini dimiliki oleh sekolah vokasi khususnya laboratorium pengelasan listrik dan asetelin juga belum memiliki sarana dan prasarana penunjang yang fleksibel dan ergonomis. Padahal, laboratorium tersebut digunakan untuk praktikum bagi mahasiswa, penelitian bagi dosen dan mahasiswa serta sering pula sebagai media untuk pengabdian masyarakat terhadap siswa-siswa SMK. Kondisi praktikan / peneliti pun tidak semua sama; tinggi, rendah, sehat jasmani (fisik) maupun memiliki cacat fisik.Untuk itu, diperlukan prasarana dan sarana pada laboratorium tersebut yang dapat mengakomodasi semua kelemahan praktikan. Laboratorium juga harus dapat memberikan materi - materi praktek yang mendasar dan lengkap sehingga dapat memberikan gambaran umum bila terjun di lapangan kerja, khususnya untuk pengelasan listrik.Untuk memenuhi hal tersebut di atas maka perlu ditunjang peralatan las yang memadai, yaitu peralatan las yang ergonomis sehingga dapat mengurangi kelelahan otot akibat posisi yang 
kurang ergonomis dan dapat memberikan keamanan, kenyamanan serta kemudahan - kemudahan. Pekerja yang mengalami kekelahan bisa berakibat pada kesulita dalam konsentrasi dan mudah terganggu, koordinasi tangan-mata berkurang dan persepsi visual, kewaspadaan berkurang dan sebagainya [1].

Pada umumnya laboratorium las listrik yang ada hanya memiliki meja persegi yang dibuat dari kerangka besi, bahkan ada yang tidak tidak memakai meja. Berdasarkan pengamatan dilapangan khususnya di perguruan tinggi/ sekolah - sekolah teknik yang belum maju hanya tersedia meja persegi dengan kerangka besi, bahkan terkadang hanya ditempatkan di lantai dengan diberi landasan besi sebagai tempat pengganti meja las. Sehingga kualitas latihan / materi yang diberikan hanya untuk las - las pada posisi mendatar saja. Kenyataan di lapangan, posisi pengelasan tidak hanya mendatar, tapi berbagai macam posisi yaitu; mendatar, horisontal, vertikal serta posisi pengelasan di atas kepala [2].

Penulis akan menganalisis dimensi-dimensi meja las, seperti tinggi tempat peluncuran, dimensi dan kontruksi meja yang dapat memberikan kemudahan melakukan praktik las dengan berbagai posisi pengelasan Dari latar belakang tersebut diatas penulis ingin merancang peralatan las listik khususnya meja, yang ergonomis dan fleksibel untuk latihan mengelas dengan berbagai macam posisi pengelasan dengan aman, nyaman dan mudah penggunaan dan sederhana, tetapi dapat memberikan gambaran keadaan kasus-kasus pengelasan yang sebenarnya di lapangan.

\section{METODE PENELITIAN}

Penelitian ini dilakukan di laboratorium sistem manufaktur Universitas Widya Mataram Yogyakarta, sedangkan obyek penelitian adalah meja las. Pada penelitian ini akan merancang meja las yang ergonomis. Dalam hal ini, pokok penelitian yang akan dirancang ulang adalah dimensi dari meja las yaitu: panjang meja, lebar meja, tinggi peluncur naik dan turun meja las, tinggi meja dan handle pengatur.

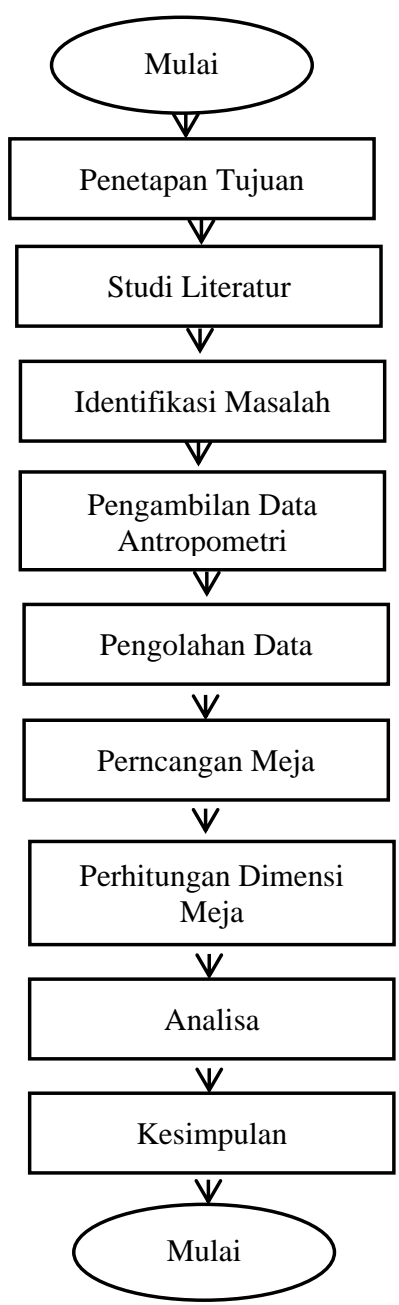

Gambar 1. Diagram Alir Penelitian 


\section{HASIL DAN PEMBAHASAN}

Dalam pembahasan masalah diuraikan macam posisi pengelasan, prinsip dasar perancangan meja las listrik, perhitungan dimensi tinggi peluncur meja las pada posisi pengelasan desain orang normal dan untuk orang cacat kaki, cara kerja, konstruksi dan materialnya, cara mengatasi kelelahan dan pengembangan meja las listrik.

\subsection{Macam-Macam Posisi Pengelasan}

Bagi orang teknik yang mendalami las listrik/asetelin tentunya mengenal peralatan-peralatan las listrik, penunjangnya dan macam-macam posisi pengelasan adalah:

a. Posisi mendatar benda kerja di depan kita dengan posisi di bawah tangan membentuk siku dan terdiri dari arah memanjang dan melintang.

b. Posisi vertical (tegak lurus): posisi dimana benda kerja tegak lurus terhadap bidang pandangan, terdiri dari arah memanjang dan melintang.

c. Posisi diatas kepala; benda kerja berada di atas kepala pengelas.

Ditinjau dari tingkat kesulitan dari ketiga posisi pengelasan tersebut, maka posisi pengelasan diatas kepala adalah posisi yang paling sulit dilaksanakan dan banyak ,menyebabkan kelelahan pada tulang tengkuk dan tangan, kemudian posisi vertical dan terakhir posisi horizontal.

Prinsip Dasar Perancangan Meja Las Listrik

Prinsip dasar perancangan produk adalah [3]:

a. Sederhana; artinya konstruksi, bentuk dan peralatanya sederhana, pembuatannya mudah dan jum;lah komponen tidak terlalu banyak (rumit),tetapi dapat memberikan kinerja dan manfaat yang tinggi,aman dan nyaman dalam pemakakiannya.

b. Fleksibel; artinya rancangan tersebut dapat digunakan dalam beberapa posisi pengelasan

c. Ergonomis; sesuai dengan aspek-aspek fisik dan psikologis si pengguna.

Perhitungan Dimensi

Untuk memudahkan perhitungan dimensi meja las, maka dimensi dari meja las listrik yang akan dihitung ditentukan terlebih dahulu [4].

1. Perhitungan Dimensi tinggi peluncur naik dan turun meja las $(\mathrm{H})$

Dimensi tinggi peluncuran meja $(\mathrm{H})$ diperuntukkan untuk pisisi pengelasan diatas kepala yaitu tinggi maksimum untuk orang dewasa dan laki-laki menurut standar orang Indonesia (dalam hal ini sama dengan orang hongkong), selain itu meja ini dirancang untuk pengelasan diatas kepala pengelasnya dalam kondisi duduk dikursi. Perhitungan ini didasarkan pada data antropometri.

Dimensi H (tinggi pip apeluncur meja untuk naik dan turun yaittu pada posisi pengelas berdiri) adalah sebagai berikut:

Dimensi : tinggi peluncur meja $(\mathrm{H})$

Percentile : 95 percentile laki-laki dalam kondisi berdiri

Allowance : $20 \mathrm{~cm}$ (tinggi sepatu)

Perhitungan= data anthropometri 95\% man (dimensi 24+allowance+0,5 d

$(\mathrm{d}=$ diameter pipa peluncur $=80 \mathrm{~mm})=2105+20+40=2165 \mathrm{~mm}$

Kettering : 95 percentile laki-laki posisi berdiri,dengan asumsi jangkauan tanagn kanan

Laki-laki lebih panjang dari wanita.

2. Dimensi tinggi meja $(\mathrm{Hm})$ untuk pengelasan diatas kepala

a. Ukuran orang normal (sehat fisik)

Untuk ukuran orang normal, pengelasan diatas kepala dilakukan dengan berdiri, dimensi Hm adalah

Dimensi : tinggi meja (Hm)

Percentile : 5 percentile wanita

Allowance : $20 \mathrm{~cm}$

Perhitungan $=$ data antropometrics $5 \%$ woman $($ dimensi $3+$ dimensi 19$)+$ allowance +0.5 panjang elektroda

$=(1180+360+20+150) \mathrm{mm}=1710 \mathrm{~mm}$

b. Ukuran orang cacat fisik (cacat kaki)

Pengelasan diatas kepala untuk orang cacat fisik, dilakukan dengan duduk di atas kursi roda sehingga dimensi Hm adalah :

Dimensi : tinggi meja ( $\mathrm{Hm}$ )

Percentile : 5 percentile wanita 
Perhitungan $=$ tinggi kursi roda + data anthropometri 5\% woman $($ dimensi $8+$ dimensi 19$)+0.5$ panjang elektroda

$$
=(365+165+360+150) \mathrm{mm}=1040 \mathrm{~mm}
$$

3. Perhitungan dimensi $\mathrm{Hm}$ posisi pengelasan vertical arah memanjang dan melintang

a. Ukuran orang normal ( sehat secara fisik );

Pengelasan vertical dilakukan secara berdiri, dimensi $\mathrm{Hm}$ adalah :

Dimensi : tinggi meja ( $\mathrm{Hm}$ )

Percentile $: 5$ percentile wanita

Allowance : $20 \mathrm{~mm}$

Perhitungan $=$ data anthropometri $5 \%$ woman $($ dimensi 4$)+$ allowance

$=(870+20) \mathrm{mm}=890 \mathrm{~mm}$

b. Untuk ukuran orang cacat secara fisik (cacat kaki);

Posisi pengelasan vertical dilakukan dengan duduk diatas kursi roda, dimensi Hm adalah :

Dimensi : tinggi meja ( $\mathrm{Hm}$ )

Percentile : 5 percentile wanita

Perthitungan $=$ tinggi kursi roda + data anthropometri 5\%woman (dimensi 9 )

$$
=(365+165) \mathrm{mm}=530 \mathrm{~mm}
$$

4. Perhitungan dimensi Hm pada posisi pengelasan mendatar untuk arah memanjang dan melintang

a. Ukuran orang sehat normal;

posisi pengelasan mendatar dilakukan dengan berdiri sehingga dimensi Hm adalah :

Dimensi : tinggi meja ( Hm )

Percentile : 5 percentile wanita

Alowance $: 20 \mathrm{~mm}$

Perhitungan $=$ data anthropometri $5 \%$ woman $($ dimensi 4$)+$ allowance -0.5 panjang elektroda $0.5 \mathrm{~d}$

$$
=(870+20-150-40) \mathrm{mm}=700 \mathrm{~mm}
$$

b. Untuk ukuran orang cacat secara fisik (cacat kaki);

posisi pengelasan mendatar dilakukan dengan duduk diatas kursi roda, dimensi Hm adalah :

Dimensi : tinggi meja ( Hm )

Percentile : 5 percentile wanita

Allowance : $20 \mathrm{~mm}$

Perhitungan = data anthropometri 5\%woman (dimensi $9-0.5$ panjang elektroda $-0.5 \mathrm{~d}$ ) $=(365+165-150-40) \mathrm{mm}=340 \mathrm{~mm}$

Keterangan : digunakan $5 \%$ wanita pada posisi duduk karena jangkauan panjang tangan perempuan lebih pendek dari pada laki-laki.

5. Penentuan dimensi P dan Q (panjang dan Lebar meja);

Dimensi panjang meja (P) dan lebar (Q) dapat menyesuaikan luas ruangan yang tersedia dengan memperhatikan factor ergonomisnya. Prinsip dasarnya adalah bentuknya ramping, aman, tidak makan tempat dan memberikan keleluasan untuk menempatkan benda kerja, untuk itu penulis menggunakan nilai $\mathrm{P}$ dan $\mathrm{Q}=400 \mathrm{~mm}$.

6. Penentuan dimensi L (Panjang peluncur meja kekiri dan kekanan);

Untuk memberikan keleluasan meja las bergerak ke samping (kiri dan kanan), maka penentuannya didasarkan pada perhitungan tempat dan berat. Dengan pertimbangan tersebut, maka dimensi L adalah :

$$
\mathrm{L}=2 \times 400=800 \mathrm{~mm}
$$

7. Dimensi ( handel pengatur);

Yang berfungsi untuk mengatur posisi meja naik turun dan berputar, sesuai dengan yang diinginkan dan yang paling enak. Menurt data anthropometri gambar dimensi tubuh pada No:22, maka dimensi $\mathrm{t}$ ditambah allowance $=150$

$$
\begin{array}{ll}
\text { Dimensi } & : \mathrm{t} \\
\text { Percentile } & : 95 \text { laki-laki } \\
\text { Allowance } & : 40 \mathrm{~mm} \\
\text { Perhitungan } & =110+\text { Allowance } \\
& =110+40=150 \mathrm{~mm}
\end{array}
$$

3.2 Pemakaian, Konstruksi dan Materian Meja Las

1. Pemakaian dan konstruksi meja las.

Konstruksi meja dapat digunakan untuk segala macam ukuran tinggi pengguna. Cara penggunaannya sangat mudah dan fleksibel; untuk berbagai posisi, dengan menaikkan dan menurunkan meja sesuai 
dengan ketinggian. Untuk posisi duduk meja ini diatur dengan mengendorkan dan mengencangkan handle. Bila kita bandingkan dengan meja yang sifatnya tetap seperti yang sering kita jumpai maka meja rancangan ini sangat jauh perbedaannya. Untuk melakukan berbagai macam posisi pengelasan cukup memutar-putar meja dengan mengendorkan dan mengencangkan handle 3. Untuk meletakkan benda kerja maka disediakan penjepit (sepeti tang) di kedua ujungnya. Hal ini dilakukan untuk mempermudah melakukan pengelasan terutama untuk tingkat pemula, terutama untuk posisi pengelasan vertical dan posisi di atas kepala.

2. Material meja las listrik

Perlu diperhatikan dalam pemilihan material yakni dengan menggunakan plat baja yang ringan tapi cukup kuat. Alasannya adalah untuk kemudahan (ringan) dalam merubah posisinya (diputar-putar), karena kontruksi ini sangat sederhana dan belum dilakukan pengembangan. Meja dibuat dari bahan yang agak tebal yaitu dari plat setebal $0.3-0.75 \mathrm{~cm}$. Tempat peluncur baik peluncur meja ke kiri, ke kanan, ke atas dan ke bawah menggunakan pipa dengan diameter nominal $8 \mathrm{~cm}$ dan tebal $2.5-3.5$ $\mathrm{mm}$. Hal tersebut dilakukan untuk menghindari kerusakan akibat penekanan handle pengencang ( handle pengatur posisi). Untuk mempermudah pergerakan posisi maka perlu perawatan yakni di beri minyak pelumas (greas) agar tidak seret (sulit digerakkan).

Cara mengatasi kelelahan yang terjadi pada pemakaian meja las

1. Kelelahan

Kelelahan mungkin terjadi akibat posisi postur tubuh pada waktu pengelasan yang antara lain :

a. Kelelahan pada tengkuk ketika melakukan pengelasan di atas kepala. Hal ini terjadi karena ketegangan saraf pada tengkuk disaat melakukan pengelasan di atas kepala.

b. Kelelahan pada lengan, terjadi karena posisi pengelasan yang bermacam-macam, sehingga saraf otot tangan dan tengkuk menjadi tegang.

2. Cara mengatasi kelelahan.

a. Kelelahan tengkuk; yaitu dengan cara melihat keatas tanpa terlalu menengadah, dengan cara membengkokkan elektroda las ketika pengelasan diatas kepala.

b. Kelelahan pada tangan; diatasi dengan cara memberikan sandaran tangan, pada perencanaan meja las tersebut yang bisa diatur tinggi rendahnya dan posisi memutarnya, yang akan di bicarakan pada pengembangan.

c. Kelelahan pada kaki; diatasi dengan cara mengurangi berdiri, dan fasilitas meja yang dirancang ini kelelahan pada kaki dapat teratasi, karena posisi yang kita meja las dapat di atur tinggi rendahnya sampai pada posisi yang kita inginkan.

3.3 Pengembangan meja las listrik

Pengembangan ini dilakukan dengan menambahkan peralatan system pengaturan pada kontruksi meja las yakni :

1. Pada peluncur meja untuk naik turun;

Bila semula meja digerakkan secara manual, maka pada pengembangannya ditambah dengan dibantu roa gigi ulir yang digerakkan oleh motor listrik, sehingga bila kita ingin mengatur posisi seperti yang diinginkan kita tinggal menekan tombol yang dihubungkan dengan motor listrik tersebut.

2. Pada peluncur meja kekiri-kekanan dan memutar;

Dikembangkan dengan tambahan peralatan roda gigi baik secara manual maupun dengan digerakkan oleh motor listrik.

3. Penambahan meja sandaran (penumpu siku tangan);

Terutama bagi pengelas pemula. Dasarnya berprinsip pada membuat meja untuk perkuliahan yaitu meja dan kursi jadi satu, artinya mejanya menempel pada kursinya dimana posisi meja berada disamping kanan kita. Meja ini juga ditambah meja penyandar siku tangan baik untuk pengelasan posisi mendatar (horisontal), vertical maupun di atas kepala, dengan tujuan untuk mengurangi getaran dan mengatasi kelelahan tangan. Meja penyandar diletakkan pada peluncur meja naik turun di bawah peluncur meja yang memutar. Konstruksi meja penyandar sama lasnya, hanya materialnya lebih tipis, ringan dan pemutar pipa peluncur lebih kecil. 


\section{SIMPULAN}

Dalam merancang meja las listrik pada suatu laboraturium yang ergonomis adalah tidak sulit dan tidak mahal, konstruksi sederhana, material terjangkau dan tanpa melakukan perhitungan yang rumit. Rancangan meja ini mempunyai banyak kelebihan bila dibandingkan dengan meja las biasa diantaranya lebih fleksibel dan diharapkan dapat mengurangi kelelahan.

Setelah dilakukan perancangan meja las yang ergonomis dan fleksibel maka didapatkan ukuran meja sebagai berikut:
L: lebar meja
: $400 \mathrm{~mm}$
P: panjang meja
: $400 \mathrm{~mm}$
$\mathrm{H}$ : tinggi peluncur naik dan turun meja las
$: 2165 \mathrm{~mm}$
Hm: tinggi meja
: $800 \mathrm{~mm}$
$\mathrm{t}$ : handle pengatur
: $150 \mathrm{~mm}$

\section{DAFTAR PUSTAKA}

[1] Kuswana, W., S. (2017). Ergonomi dan K3. Bandung: PT. Remaja Rosdakarya

[2] Jazuli., Susanto, D.N., Setyaningrum, R. 2015. Analisis Dan Perancangan Meja Las Dengan Pendekatan Ergonomi Dan QFD. Seminar Nasional IENACO. ISSN 2337-4349.

[3] Nurmianto, E. (1997). Ergonomi Dan Aplikasi Perancangan Untuk Industri. Surabaya. Diktat Pelatihan Dosen, Jurusan Teknik Industri Institut Teknologi Sepuluh Nopember.

[4] Nurmianto, E. (1996). Ergonomi Konsep Dasar Dan Aplikasinya. Jakarta: PT. Guna Widya.

[5] Sanders, M., S., and McCormick, E. (1993). Human Factor In Engineering And Design. New York: McGraw-Hill. 